University of Nebraska - Lincoln

DigitalCommons@University of Nebraska - Lincoln

USDA National Wildlife Research Center - Staff Publications
U.S. Department of Agriculture: Animal and Plant Health Inspection Service

September 1993

\title{
Toward Conservation of Midcontinental Shorebird Migrations
}

\author{
Susan K. Skagen \\ National Ecology Research Center, United States Fish and Wildlife Service \\ Fritz L. Knopf \\ National Ecology Research Center, United States Fish and Wildlife Service
}

Follow this and additional works at: https://digitalcommons.unl.edu/icwdm_usdanwrc

Part of the Environmental Sciences Commons

Skagen, Susan K. and Knopf, Fritz L., "Toward Conservation of Midcontinental Shorebird Migrations" (1993). USDA National Wildlife Research Center - Staff Publications. 646.

https://digitalcommons.unl.edu/icwdm_usdanwrc/646

This Article is brought to you for free and open access by the U.S. Department of Agriculture: Animal and Plant Health Inspection Service at DigitalCommons@University of Nebraska - Lincoln. It has been accepted for inclusion in USDA National Wildlife Research Center - Staff Publications by an authorized administrator of DigitalCommons@University of Nebraska - Lincoln. 


\title{
Toward Conservation of Midcontinental
}

\section{Shorebird Migrations}

\author{
SUSAN K SKAGEN
}

National Ecology Research Center

United States Fish and Wildlife Service

Fort Collins, CO 80525, U.S.A.

\section{FRITZ L. KNOPF}

National Ecology Research Center

United States Fish and Wildlife Service

Fort Collins, CO 80525, U.S.A.

\begin{abstract}
Sborebirds represent a bighly diverse group of spe. cies, many of wbicb experience tremendous energy demands associated witb long-distance migratory flights. Transcontinental migrants are dependent upon dynamic fresbuater uetlands for stopover resources essential for replenisbment of lipid reserves and completion of migration. Patterms of shorebird migratton across midcontinental wetlands were detected from migration reports to American Birds and infarmation provided by U.S. Fish and Wildlife Service national willife refuges. Patterns in species composition and abundance varted geographically, empbastizing the uniquemess of different regions to migrating sborebirds. Smaller species and neotropical migrants moved primarily across the Great Plains, whereas langer species and Nortb American migrants predomtnated in assemblages in the intermountain west Sbonebirds uere broadly dispersed in uetland babitats with dynamic water regimes. Whereas populations of sbonebirds in coastal systems appear to concentrate at sites of seasonally predictable and abundant food resources, we propose that transcontinental sbonebirds disperse and use uetlands opportunistically. This migration system exemplifies the need for lange-scale, coordinated regional management efforts that recognize the dynamic nature of ecosystem processes.
\end{abstract}

Papper submitted Janwary 3, 1992; reutsed manuscript accepted September 4, 1992.
Hacia la conservación de las migraciones de aves costeras del continente medio

Resumen: Las aves costeras representan un grupo de espe. cies muy diverso, mucbos de las cuales experimentan demandas energéticas tremendas asociadas con vuelos migratorios de largo alcance. Los migrantes continentales dependen de la dinámica de los bumedales para obtener recursos esenciales para el reabastecimiento de las reseruas de lipidos y para llevar a cabo la migración. Patrones de migracion de aves que atravtesan bumedales del continente medio fueron detectados a partir de reportes de migración de "American Birds" y de información provista por los nefugios Nacionales para vida silvestre del Servicio Nactonal de Pesca $y$ Vida Silvestre de los Estados Unidos ("U.S. Fisb and Wildiffe Service"). Los patrones de composición de especies y abundancia varianon geográficamente, enfatizando la singularidad de las difenentes regiones para las aves migratorias. Las especies pequentas y los migrantes neotropicales se trasladanon principalmente a través de las Grandes Plantcies, mientras que espectes más grandes $y$ migrantes de Norte América predominaron en grupos en el oeste intermontañoso. Las aues costeras estuvieron ampltamente dispersadas en bábitats de bumedales con regimenes de agua dinamicas Dado que en los sistemas costeros las poblactones de aves costeras parecen concentrarse en sittas con recursos alimenuctos abundantes $y$ estacionalmente predecibles, nosotras proponemos que las aues costeras transcontinentales se dispersan y usan los bumedales en forma oportunistica Este sistema de migración ejemplifica la necesidad de esfuerzos regionales coondinados y a gran escala que reconozcan la naturaleza dinámica de las procesos ecosistémicos. 


\section{Introduction}

Several species of shorebirds (Cbaradritormes: Charadritdae, Scolopacidae, Pbalaropodidae) migrate long distances between arctic and subarctic breeding grounds to Central and South American nonbreeding areas. The tremendous energy demands associated with flights of several thousand kilometers require that birds be able to repeat the cycle of accumulating then using substantial lipid reserves (Morrison 1984; Myers et al. 1987). Because long-distance migrants cannot make the journey without periodically replenishing fat reserves, stopover sites become critical to the survival of many of these species (Myers 1983; Morrison 1984; Myers et al. 1987).

Three major flyways or main migration corridors link breeding and wintering sites across the Western Hemisphere (Morrison 1984; Morrison \& Myers 1989:90). Current views on the migration of shorebirds are derived primarily from studies of the coastal Atlantic and Pacific flyways. In coastal areas, several species of shorebirds stop at relatively few sites where food is abundant and predictable (Morrison 1984:139; Morrison \& Myers 1989:85). There are probably no alternative coastal sites that could provide enough food for these large aggregations of shorebirds at precisely the right times to ensure successful migration (Senner \& Howe 1984).

In contrast to coastal areas, the dynamic patterns of rainfall and hydrology in the Great Plains result in extreme spatial and temporal variability in both occurrence and condition of wetlands. Large permanent wetlands may provide the most predictable resources for interior migrants, but even they are less predictable than coastal intertidal areas.

Shorebirds as a group are extremely diverse in body size and shape as well as in habitat-use patterns and foraging behavior. Migrants in the Western Hemisphere span ranges of $130-650 \mathrm{~mm}$ in body length, 13-219 $\mathrm{mm}$ in bill length, and 17-92 $\mathrm{mm}$ in tarsal length (Hay. man et al. 1986). Patterns of microhabitat use are determined in part by species morphology (Baker 1979, Colwell \& Oring 1988). Collectively, shorebirds use a broad range of habitats, including grassy uplands, wet meadows, unvegetated mud substrates, shallow water, and deeper open water (Colwell \& Oring 1988). While feeding, shorebirds glean invertebrates from the surface of mud, water, or emergent vegetation, probe deeply into moist soil, or even catch flying insects.

This paper addresses regional patterns of stopover use and distribution of the diverse group of migrant shorebirds that use continental wetlands. We examined reports to American Birds and responses to our own questionnaires to national wildlife refuges designed to identify spatial patterns and regional differences in shorebird use of these wetlands. Specifically, we sought to clarify the relative use of wetlands in the central plains and intermountain areas by neotropical-migrating shorebirds enroute between arctic breeding grounds and Central and South American wintering grounds. This paper represents part of ongoing research on shorebird migration systems. Findings will be used to develop plans for protection and management of stopover areas in the interior U.S.

\section{Methods}

We compiled totals of all shorebirds reported to Amer. ican Birds from 11 states during 10 years of southward and northward migrations from late summer and fall of 1979 through the spring of 1990 . For ambiguous entries ("were noted at," "dropped in," "in diminished numbers," "handful," "few," "several," "numerous"), we assigned conservative values ranging from 2 to 20 . Because shorebirds (with the exception of phalaropes) are primarily limited to water depths proportional to leg length and body size, we classified shorebirds by size after Morrison and Ross (1989). Small birds are primarily small sandpipers and plovers in the genera Calidris and Charadrius with total body lengths of $\leqslant 190 \mathrm{~mm}$ (Appendix). Medium-sized shorebirds range in body length from 195 to $350 \mathrm{~mm}$, and large birds exceed $350 \mathrm{~mm}$.

We also classified shorebirds by migration distance (short, intermediate, and long) based on range maps in Hayman et al. (1986) and maps in the National Geographic Society Atlas (1981). We calculated an index $I$ $(\times 1000 \mathrm{~km})$ as a weighted average of $D_{s}, D_{m}$ and $D_{e}$ where $D_{s}=$ the shortest distance between breeding and wintering areas (if areas overlap, $D_{s}=0$ ), $D_{m}=$ distance between estimated midpoints of breeding and wintering ranges, and $D_{e}=$ distance between extremes of breeding and wintering areas (Fig. 1 ; Appendix). $I$ is highly correlated ( $r=0.97)$ with $D_{m}$, the distance between midpoints of breeding and wintering areas.

We mailed questionnaires to 100 U.S. Fish and Wildlife Service national wildlife refuges in 18 states in the Great Plains and intermountain regions, requesting information on shorebird use of refuges and adjacent lands during northward (April-May 1990) and southward (August-September 1990) migrations. Respondents were asked to categorize peak shorebird abundance as 1-100, 100-500, 500-1000, 1000-2000, $2000-5000,5000-10,000$, and $>10,000$ birds and to estimate percentages of small, medium-sized, and large birds (phalaropes included among medium-sized birds for ease of identification). Additional information requested from refuges included the total surface area of water (AREA), the number of discrete water units (UNIT) on the refuges during migration, and rank estimates of the amount of available shorebird habitat. We 


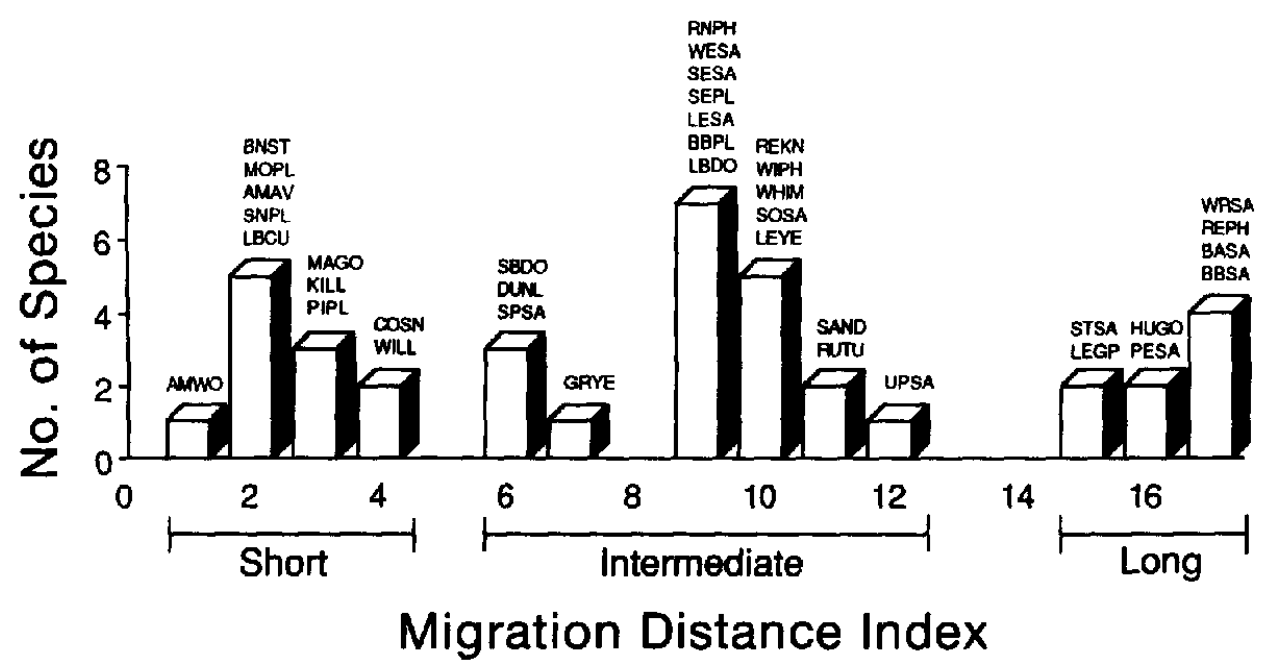

Figure 1. Classification of sborebirds by migration distance (sbort, intermediate, and long) based on a migration distance index, the weighted average of $\mathrm{D}_{s}, \mathrm{D}_{m}$, and $\mathrm{D}_{c}$, where $\mathrm{D}_{s}=$ the sbortest distance between breeding and wintering areas, $\mathrm{D}_{\mathrm{m}}=$ the distance between estimated midpoints, and $\mathrm{D}_{\mathrm{c}}=$ the distance between extremes of breeding and wintering areas. All measurements were based on maps in Hayman et al (1986) and the National Geograpbic Society Atlas (1981). See Appendix for species identification.

asked for area estimates in English units because refuge personnel use English units more commonly than metric units. We then converted areas to the following metric categories: $1=<4$ ha, $2=4-20 \mathrm{ha}, 3=20-80 \mathrm{ha}$, $4=>80$ ha. Habitat types were expressed as $A=$ wet mud and water $<2.5 \mathrm{~cm}$ and $B=$ shallow water $2.5-20$ cm deep. Rank estimates of $A$ and $B$ were totalled to provide an overall estimate of shorebird habitat (HAB). We also included information from one state-owned refuge, Cheyenne Bottoms Wildlife Management Area, Kansas.

Calculations of maximum reported shorebird numbers were based on midpoints of the first six categories above $(50,300,750,1500,3500$, and 7500$)$. A shorebird abundance of $>10,000$ was assigned as 10,000 (i.e., no midpoint), resulting in a conservative estimate. To examine seasonal differences in refuge use, we evaluated information from 80 refuges that submitted both spring and fall responses. Precision of the data do not merit quantitative assessments of dispersion. AREA and UNIT were $\log$ transformed for statistical procedures below.

We recognize the potential biases in data that are not based on systematic surveys. Such sources of data, however, can reveal continent-wide patterns of avian geographical ecology (Bock \& Root 1981) that may otherwise go undetected. We assumed that the responses to refuge questionnaires held no regional biases in estimated numbers or classification of birds by body size. We also assumed that, over a ten-year period, there were collectively no regional biases in the relative frequencies of species reported to American Birds.

\section{Results}

Geographic Patterns in Shorebird Distribution During Migration

Use of wetlands by shorebirds was stratified across six regions in the Great Plains and intermountain areas. Below we contrast bird use of the intermountain states represented in this study (Nevada, Utah, Idaho, western Montana) with bird use of the central plains (eastern Alberta, Saskatchewan, Manitoba, eastern Montana, North Dakota, South Dakota, Nebraska, Kansas, Oklahoma).

In spring, the intermountain area hosts primarily short-distance migrants and species whose breeding range lies south of $65^{\circ} \mathrm{N}$ (Fig. 2; Table 1). In contrast, long-distance migrants and species that breed exclusively north of $60^{\circ} \mathrm{N}$ stop primarily in the central plains for replenishing reserves (Fig. 2; Table 1). During fall migration, species that winter in the U.S. are more heavily represented in the intermountain region than in the plains, whereas species that travel south of the equator are more heavily represented in the plains (Table 1).

Grouping shorebirds by body size also revealed a striking pattern. During spring migration, small shorebirds comprised a larger proportion of populations in the central plains than in the intermountain areas, according to reports to American Birds (Fig. 3; $G=$ 1618.28, $d f=1, p<0.001$ ). This pattern was substantiated by our own data (unpublished), which reveal even greater percentages ( $50-70 \%)$ of small birds in 


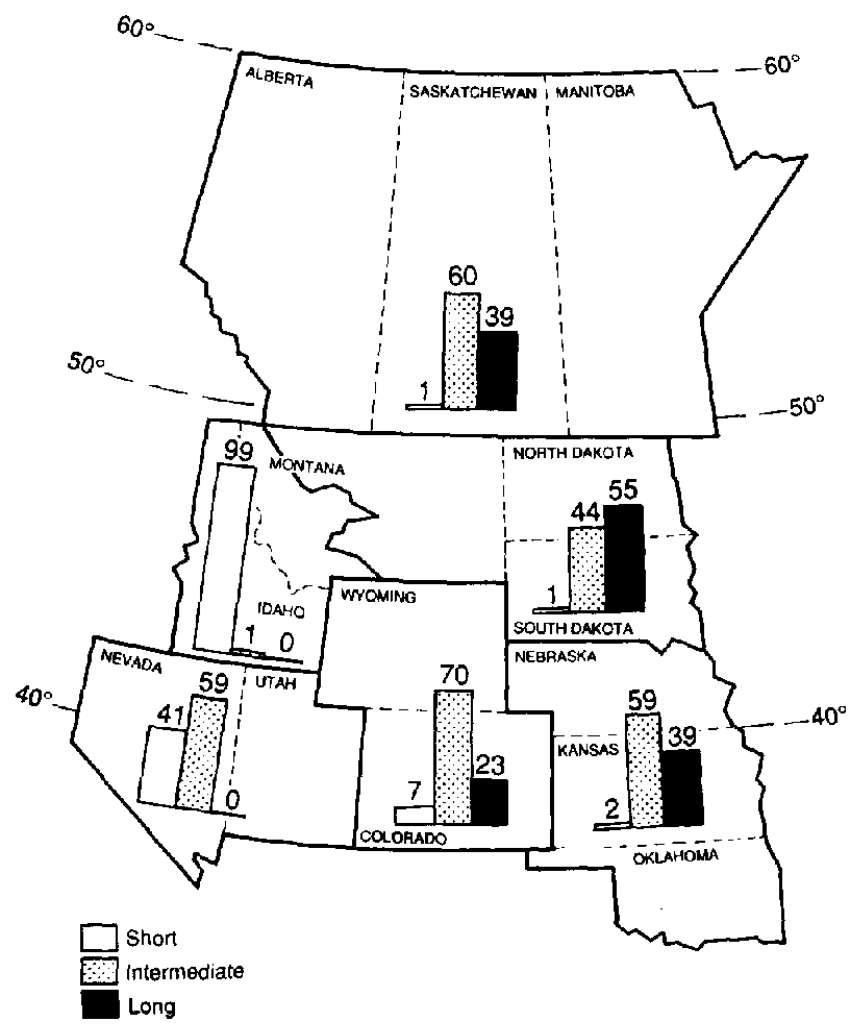

Figure 2. Geographic distribution of shorebirds by migration distance during spring migration. Bar graphs and numbers depict percentage of sbort, intermediate, and long-distance migrants witbin six regions designated by solid lines. Data from American Birds spring migration reports 1980-1990. See Appendix for classification of sborebird species by migration distance.

the central plains. Large shorebirds were more heavily represented in the intermountain regions than in the central plains (Fig. 3; $G=204.99, d f=1, p<0.001$ ). Medium-sized shorebirds were a large proportion $(\geqslant 50 \%)$ of aggregations throughout the 11 states and 3 provinces, except in western Montana and Idaho. Phalaropes were not reported in Idaho and western Montana, whereas they were $9-21 \%$ of the mediumsized shorebirds from North Dakota south of Oklahoma and $33-56 \%$ of the medium-sized shorebirds in the remaining states and provinces.

The greatest number of species was reported in the central Canadian plains in spring, and the smallest number of species in the northern intermountain area (Table 1). Abundance of species differed substantially by region (Table 1). For example, White-Rumped Sandpipers were reported only in the three eastern regions during spring, whereas Long-Billed Dowitchers were among the most abundant species only in the three southern regions.

\section{Dynamics of Water Levels and Shorebird Habitat on Refuges}

During both spring and fall migration, total water area (AREA) on refuges correlated highly with estimated potential shorebird habitat (HAB; $r=0.521, d f=73, p<$ 0.001 for spring; $r=0.576, d f=74, p<0.001$ for fall; 1-tailed). In spring, the number of water units (UNIT) also correlated with estimates of shorebird habitat ( $r=$ $0.230, d f=73, p<0.05$ ). In both seasons, northern refuges reported more potential shorebird habitat per refuge than did southern refuges (Table 2 ).

Many refuges (69\% of 94) reported profound changes in water levels; $41 \%$ reported water present only in some years. Seventeen respondents at northern refuges, primarily in North Dakota, South Dakota, and Nebraska, perceived an increase in shorebird habitat in spring and fall of 1990 and accredited it to drought conditions. Most refuges ( $74 \%$ of 95 ) have some capability to manage water levels.

\section{Distribution and Habitat Relationships of Shorebirds on Refuges}

Shorebirds were broadly dispersed throughout the entire region during spring and during late summer and fall; 13 refuges reported more than 10,000 birds (Fig. 4). Most responses were based on best estimates of refuge personnel, although some $(21 \%$ of 90 responses in spring, $17 \%$ of 85 responses in late summer and fall) were based on ongoing surveys. Because most of the refuges were in the plains, we did not make comparisons between shorebird use of plains and intermountain areas.

In spring and fall, shorebird numbers were greater on refuges with abundant habitat (wet mud and shallow water $<2.5 \mathrm{~cm}$ ) than on refuges with sparse habitat (Table 3). The abundance of shorebirds increased with latitude in both seasons $(r=0.293, d f=89, p<0.01$ in spring; $r=0.330, d f=83, p<0.05$ in fall).

\section{Variability in the Abundance of Shorebirds within and between Seasons}

From April to May during the spring migration, respondents in northern refuges generally perceived increases and respondents in southern refuges reported decreases in the abundance of shorebirds $\left(X^{2}=14.36, d f=4, p\right.$ $=0.006$ ). These patterns were not reported for migration during late summer and fall migration $\left(X^{2}=3.86\right.$, $d f=4, p=0.43$ ).

Small shorebirds, but not medium or large shorebirds, were more numerous $(p<0.10)$ in the fall than in the spring in northern refuges (latitude $\geqslant 43^{\circ} \mathrm{N}$; Table 4 ). This trend was reversed on the southern refuges (latitude $<43^{\circ} \mathrm{N}$ ), where small shorebirds were significantly more numerous in the spring than in the fall (Table 4 ). 
Table 1. Composition of shorebirds reported in Amertcan Binds at stopover sites in six geographic reglons during spring migration, 1980-1990, and bate sammer/fill migrotion, 1979-1989.

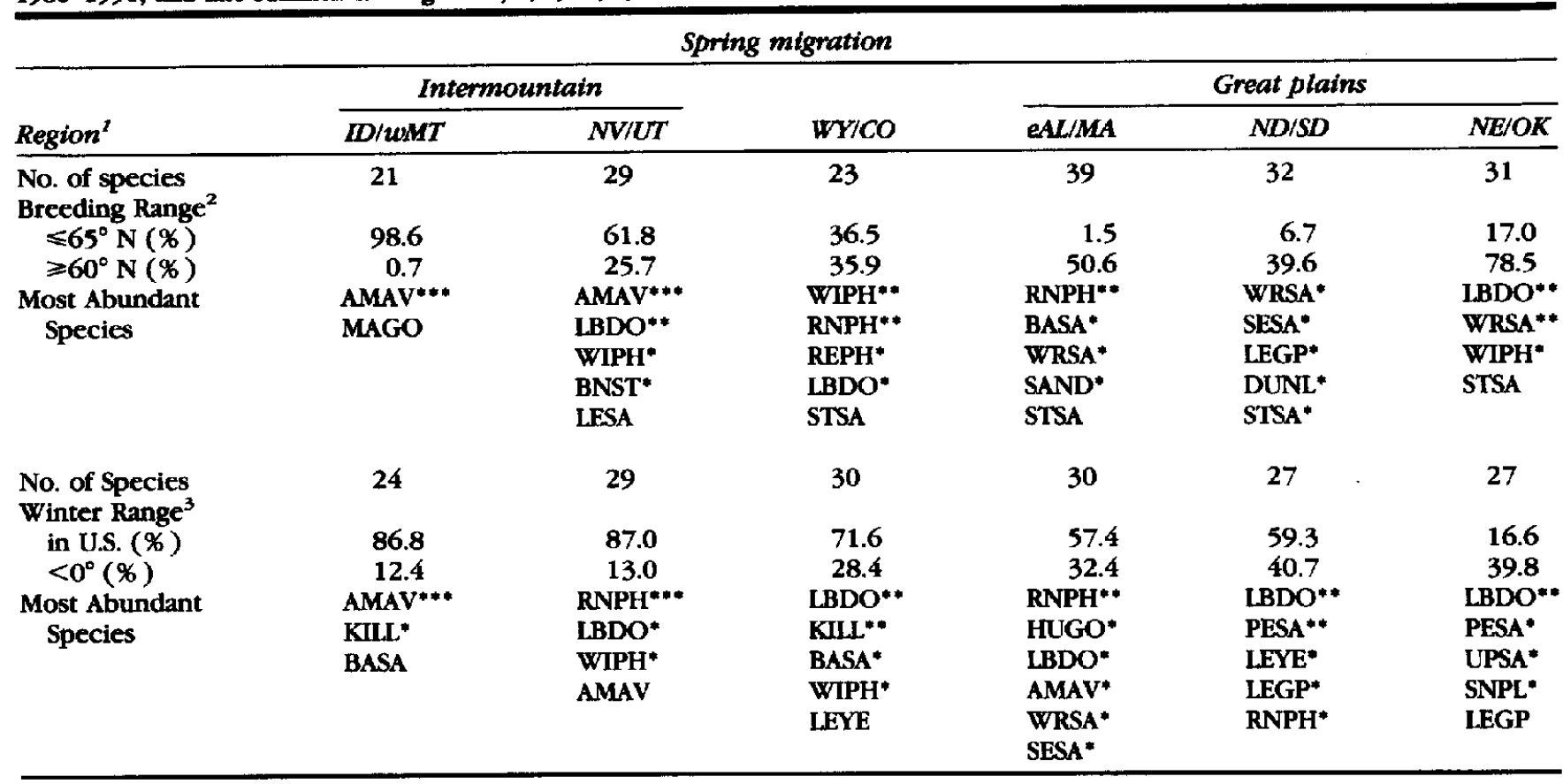

Refer to Appendix for definitions of alpha codes

Percentages are based on total numbers of birds reported in regton

$* 10 \%, * * 20 \%, \cdots+>50 \%$ of total number of birds reported in region

ID/wMT: Idabo and western Montana; NV/UT: Nevada and Utab; WY/CO: Wyoming and Colorado; eAL/MA: eastern Alberta, Saskatcbewan, and Manitoba; ND/SD: eastern Montana, Nortb Dakota, and Soutb Dakota; NE/OK: Nebraska, Kansas, and Oklahoma

${ }^{2}$ Breeding range lies exclustuely south of $65^{\circ} \mathrm{N}$ or north of $60^{\circ} \mathrm{N}$.

${ }^{3}$ Winter range is partially in U.S. or exclusively south of the equator.

Twenty-four respondents offered comments on yearto-year variability in the abundance of shorebirds related to water conditions. Of these, 10 respondents in North and South Dakota reported a greater abundance of shorebirds than expected in 1990 and attributed it to drought. Three southern refuges reported that flooding and high water drastically reduced habitat in spring, and two southern refuges reported that flooding of fields increased habitat.

\section{Consistency among Data Sets}

We compared broadscale trends derived from American Birds migration reports $(A B M R)$ and from refuge questionnaires $(R Q)$, and, when possible, checked these trends against patterns in our own recent (1990-1991) shorebird survey data from Kansas, Oklahoma, and South Dakota (NERC; unpublished data). The data sets were in general agreement for the following trends.

In spring, large shorebirds were only a minor portion of shorebird communities in the central plains $(\leqslant 5 \%$ $A B M R$ and NERC; 8-16\%,RQ), but were the major proportion of birds in wetlands in the intermountain area ( $A B M R$ and $R Q$ ). Short-distance migrants were rare in the central plains in spring ( $\leqslant 3 \%$ of sightings), but more plentiful (10-20\% of sightings) in fall (ABMR and $N E R C$ ). Long-distance migrants formed a large compo- nent of shorebird communities in the central plains in spring (35-55\%; $A B M R$ and NERC; see also Eldridge \& Johnson 1988). There were many species in the central plains in spring (31-34 species) and slightly fewer in fall (27-30; $A B M R$ and NERC). ABMR and NERC data sets were in agreement on the relative importance of springmigrant White-Rumped Sandpipers and Semipalmated Sandpipers in the Dakotas, spring-migrant WhiteRumped Sandpipers and Long-Billed Dowitchers in Nebraska, Kansas, and Oklahoma (NE/OK), and fall-migrant long-billed Dowitchers in NE/OK.

Data sets did not agree consistently. $A B M R$ and $R Q$ estimates of small shorebirds were fairly consistent for the central plains in spring ( $27-43 \%$ of sightings). However, data of NERC and of Eldridge and Johnson (1988) suggest that the percentage of small shorebirds was considerably higher ( $50-70 \%$ of assemblages). The relative importance of Wilson's Phalaropes, Lesser Golden Plovers, and Least Sandpipers differed somewhat between the $A B M R$ and the NERC data sets.

\section{Discussion}

\section{Complexity of the Interior Migration System}

Efforts to maintain regional shorebird diversity must address the complexity of this migration system. Shore- 


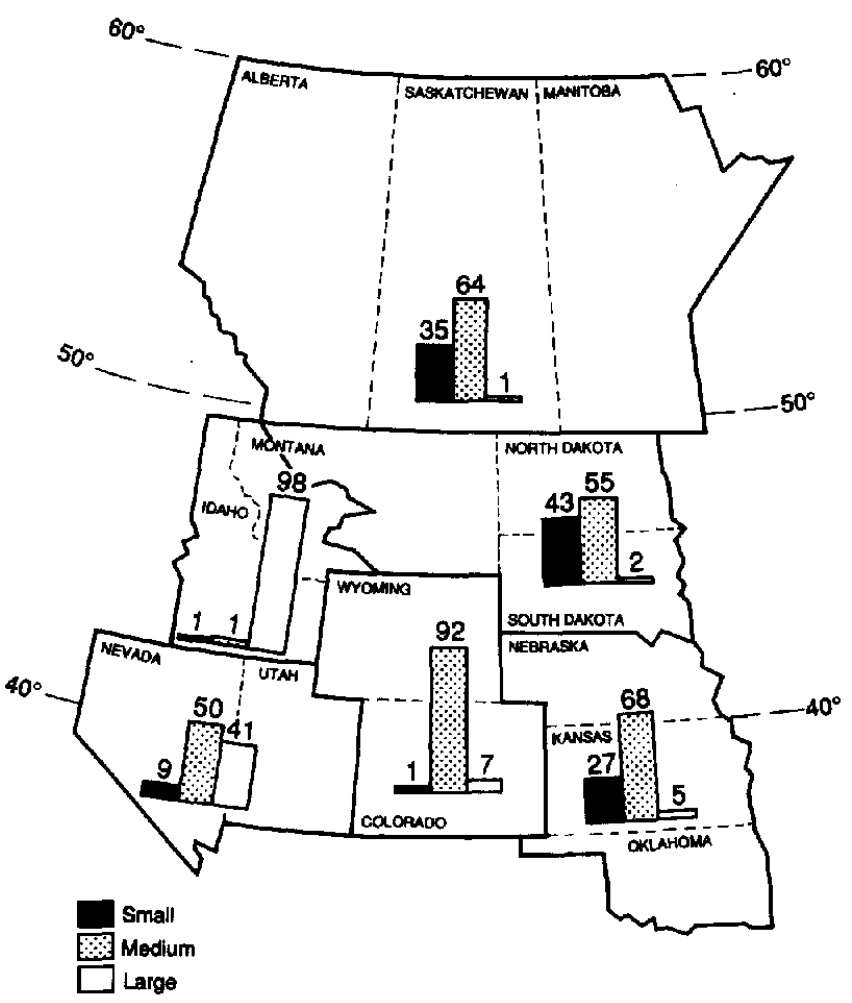

Figure 3. Geograpbic distribution of sborebirds by body size during spring migration Bar graphs and numbers depict percentage of small, medium-sized, and large shorebirds witbin six regions designated by solid lines. Data from American Birds spring $\boldsymbol{m}$ i. gration reports 1980-1990. See Appendix for classification of shorebird species by body size.

birds are broadly dispersed throughout the U.S. and Canadian interior during spring and fall migration. Species composition and abundance patterns, however, vary substantially between seasons and geographic areas; this variation clearly illustrates the uniqueness of different regions to migrating shorebirds.

Stopover sites in the Great Plains provide essential resources for long-distance and intermediate-distance neotropical migrants, such as White-Rumped Sandpiper, Baird's Sandpiper, Pectoral Sandpiper, Stilt Sandpiper, Dunlin, Hudsonian Godwit, and Semipalmated Sand-

Table 2. Iatitudinal trends in estimates of shorebird habitat on U.S. Fish and Wildife Service national wildife refuges, 1990 (numbers are refuges in each category).

\begin{tabular}{|c|c|c|c|c|c|c|}
\hline \multirow[b]{3}{*}{ Latitude } & \multicolumn{6}{|c|}{ Estimated babitat (ba) } \\
\hline & \multicolumn{3}{|c|}{ Spring } & \multicolumn{3}{|c|}{ Fall } \\
\hline & $<20$ & $20-120$ & $>120$ & $<20$ & $20-120$ & $>120$ \\
\hline $\begin{array}{l}\text { Lat } \geqslant 43^{\circ} \\
\text { Lat }<43^{\circ} \\
\text { Correlation of } \\
\text { Habitat and } \\
\text { Lattitude }(1 \%)\end{array}$ & $\begin{array}{l}7 \\
7\end{array}$ & $\begin{aligned} 15 \\
17 \\
r=0.156 \\
d f=89 \\
p>0.10\end{aligned}$ & $\begin{array}{r}25 \\
19\end{array}$ & $\begin{array}{l}5 \\
6\end{array}$ & $\begin{aligned} 14 \\
22 \\
r=0.332 \\
d f=83 \\
p<0.002\end{aligned}$ & $\begin{array}{l}26 \\
10\end{array}$ \\
\hline
\end{tabular}

piper. Birds travelling long distances are under severe physiological and ecological constraints, and resources at stopover sites are critical to their survival.

Wetlands in the central plains are of particular importance to small-bodied shorebirds that experience more constraints than larger birds. Smaller birds have higher basal metabolic rates than larger birds (Calder 1984) and are able to accumulate less body fat. Furthermore, short legs and a short bill confine small shorebirds to a narrower range of water depths than larger birds. An additional constraint that primarily affects spring rather than fall migrants is the exact timing of resource availability. In spring, resources must be available during a fairly narrow window of time in order for birds to refuel and reach their breeding grounds in time to complete the nesting cycle. This constraint is less pronounced during the more leisurely fall migration.

The intermountain area differs markedly from the Great Plains because its wetlands host many largerbodied, short-distance migrants that breed in the U.S., such as the American Avocet, Black-Necked Stilt, and Marbled Godwit, and fall migrants that winter in the U.S., such as the Least Sandpiper and Long-Billed Dowitcher. Long-distance migrants were comparatively rare in the intermountain region.

\section{Habitat Protection in Dynamic Bcosystems}

The highly dynamic nature of freshwater wetlands, described by Fredrickson and Reid (1990) and others, and substantiated by refuge reports, undoubtedly had a strong influence on the evolution of shorebird migration routes and strategies. We propose that, because wetlands are dynamic and unpredictable during migration, shorebird movements across the plains are characterized by dispersion and opportunism rather than by concentration and predictability, as in coastal systems.

The occurrence of mudflats and shallow water habitats is highly variable yet is critical to refueling efforts of small shorebirds. These ephemeral and dynamic habitats are perhaps some of the most endangered habitats in the continental U.S. because of the rapid loss of wetlands due to conversion of lands to agriculture (Tiner 1984; Dahl 1990) and extensive alteration of hydrologic processes (Fredrickson \& Reid 1990). Ephemeral and shallow wetlands will receive even less protection in the near future under the new wetlands designation policy (U.S. Environmental Protection Agency 1991).

Protection of habitat for species that use disjunct patches of habitat opportunistically or irregularly during migration is a difficult challenge that has received little attention (Takekawa \& Beissinger 1989). The dynamic nature of such systems requires a new management perspective that does not depend on the maintenance of a few sites in a static condition (Szaro 1990). Wetlands known to support large numbers of migrant shorebirds, 


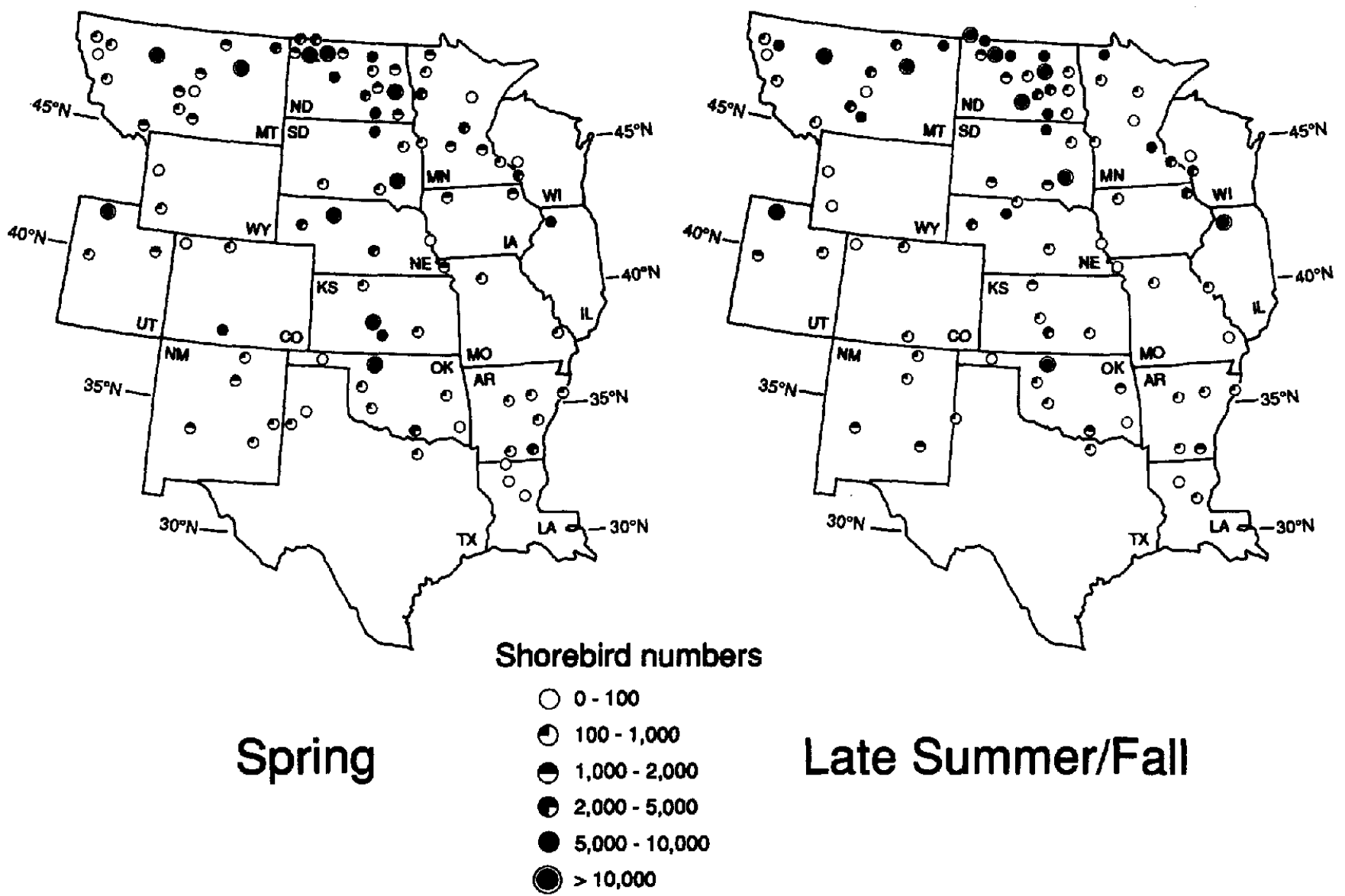

Figure 4. Distribution of shorebirds at U.S. Fish and Wildlife Service national wildife refuges (NWR) in the Great Plains and intermountain areas during spring and late summer/fall migration. Estimates are from responses by NWRs to questionnaires. Estimates from the state-ouned Cheyenne Bottoms Wildife Management Area in central Kansas are also included.

such as the Cheyenne Bottoms Wildlife Management Area in central Kansas, do not always have habitat suitable for small shorebirds during migration (Castro et al. 1990; personal observation). At these times, alternative sites become increasingly important. Also, some species require a network of sites or "stepping stones" to complete migration (Smit \& Piersma 1989), and many options must be maintained to provide those links.

Table 3. Mean \pm SB $(M)$ maximum numbers of shorebirds reported at U.S. Fish and Wildlife Service national wildife refuges relative to extimates of shorebird habitut.

\begin{tabular}{|c|c|c|}
\hline \multirow{2}{*}{$\begin{array}{l}\text { Estimated } \\
\text { babitat (ba) }\end{array}$} & \multicolumn{2}{|c|}{ Number of sborebirds } \\
\hline & Spring & Fall \\
\hline $\begin{array}{l}<20 \\
20-120 \\
>120 \\
\text { Tests of } \\
\quad \text { Significance }\end{array}$ & $\begin{aligned} 240 & \pm 100(14) \\
1570 & \pm 420(32) \\
4820 & \pm 590(43) \\
H & =40.6 \\
d f & =2,88 \\
p & <0.0001\end{aligned}$ & $\begin{aligned} 470 & \pm 190(12) \\
980 & \pm 250(35) \\
5700 & \pm 610(36) \\
H & =40.3 \\
d f & =2,80 \\
p & <0.0001\end{aligned}$ \\
\hline
\end{tabular}

Data are rounded to the nearest 10.

' Kruskal-Wallis test.
Large-scale regional management perspectives are crucial to the protection of breeding, migration, and wintering habitats for shorebirds in arctic, temperate, and tropical regions (Myers et al. 1987). Here we describe an opportunistic migration system that is very different from the coastal paradigm upon which current

Table 4. Latitudinal trends in spring and fall shorebird distribution on 44 northern $\left(\geqslant 43^{\circ} \mathrm{N}\right)$ and 36 southern $\left(<43^{\circ} \mathrm{N}\right)$ U.S. Fish and Wildife Service national wildlife refuges.

\begin{tabular}{|c|c|c|c|c|c|}
\hline \multirow[b]{3}{*}{ Body Size } & \multirow[b]{3}{*}{ Latitude } & \multirow[b]{3}{*}{$\boldsymbol{N}$} & \multicolumn{2}{|c|}{ Number of shorebirds } & \multirow[b]{3}{*}{$\boldsymbol{P}$} \\
\hline & & & Spring & Fall & \\
\hline & & & Mean $+\boldsymbol{S E}$ & $M e a n+S E$ & \\
\hline All & $\begin{array}{l}\geqslant 43^{\circ} \\
<43^{\circ}\end{array}$ & $\begin{array}{l}44 \\
36\end{array}$ & $\begin{array}{l}2960 \pm 500 \\
2560 \pm 580\end{array}$ & $\begin{array}{l}4140 \pm 570 \\
1740 \pm 480\end{array}$ & $\begin{array}{l}0.044^{\circ} \\
0.047^{\circ}\end{array}$ \\
\hline Small & $\begin{array}{l}\geqslant 43^{\circ} \\
<43^{\circ}\end{array}$ & $\begin{array}{l}43 \\
35\end{array}$ & $\begin{array}{l}1300 \pm 250 \\
1010 \pm 310\end{array}$ & $\begin{array}{r}1870 \pm 320 \\
550 \pm 180\end{array}$ & $\begin{array}{l}0.098^{* *} \\
0.024^{*}\end{array}$ \\
\hline Medium & $\begin{array}{l}\geqslant 43^{\circ} \\
<43^{\circ}\end{array}$ & $\begin{array}{l}43 \\
35\end{array}$ & $\begin{array}{l}1200 \pm 200 \\
1300 \pm 370\end{array}$ & $\begin{aligned} 1580 & \pm 240 \\
870 & \pm 260\end{aligned}$ & $\begin{array}{l}0.108 \\
0.202\end{array}$ \\
\hline Large & $\begin{array}{l}\geqslant 43^{\circ} \\
<43^{\circ}\end{array}$ & $\begin{array}{l}43 \\
35\end{array}$ & $\begin{array}{l}530 \pm 120 \\
320 \pm 120\end{array}$ & $\begin{array}{l}540 \pm 130 \\
360 \pm 240\end{array}$ & $\begin{array}{l}0.884 \\
0.754\end{array}$ \\
\hline
\end{tabular}

Data are rounded to nearest $10 . " p<0.05$. 
thinking is founded. To expand protection of shorebird habitat within continental regions, the complexity and the bynamic namre of transconimenta migraion must be addressed.

\section{Acknowledgments}

We sincerey thank personnel of the U.S. Fish and wholife Service refuges for information on shorebirds in refuges. Nancy Wells distributed refuge questionnaires and

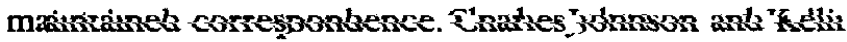
Stone compiled records from American Birds migration reports. Gonzalo Castro, Susan M. Haig, and Elizabeth Rockwell offered comments on early versions of the manuscribt.

\section{Literature Cited}

Baker, M. C. 1979. Morphological correlates of habitat selection in a community of shorebirds (Charadriiformes). Oikos 33:121-126.

Bock, C. E., and T. L. Root. 1981. The Christmas bird count and avian ecology. Studies in Avian Biology 6:17-23.

Calder, W. A., III. 1984. Size, function, and life history. Harvard University Press, Cambridge, Massachusetts.

Castro, G., F. L. Knopf, and B. A. Wunder. 1990. The drying of

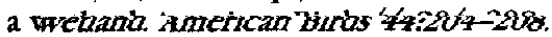

Colweil, M. A., and L. W. Oring. 1988. Habicac use by breeding and migrating shorebirds in southcentral Saskatchewan. Wilson Bulletin 100:554-566.

Dahl, T. E. 1990. Wetlands losses in the United States 1780's to 1980's. U.S. Department of the Interior, Fish and Wildlife Service, Wastingron, DK.

Eldridge, J. L., and D. H. Johnson. 1988. Size differences in migrank sandpriper flocks: Ghosts in ephemeral gailds. Decologia $77: 433-444$.

Fredrickson, L. H., and F. A. Reid. 1990. Impacts of hydrologic alteration on management of freshwater wetands. Pages $71-$ 90 in J. M. Sweeney, editor. Management of dynamic ecosystems. North Cental Section, The Wildife Soclety, West Lafayette, Indiana.

Hayman, P., J. Marchant, and T. Prater. 1986. Shorebirds: An identification guide to the waders of the world. HoughtonMifflin, Boston, Massachusetts.
Klimkiewicz, M. K, and C. S. Robbins. 1978. Standard abbreviations for common names of birds. North American Bird Bander 3:16-25.

Morrison, R. I. G. 1984. Migration systems of some New World shorebirds. Pages 125-202 in J. Burger and B. L. Olla, editors. Shorebirds: Migration and foraging behavior. Plenum Publishing, ivew Forik.

Morrison, R. I. G., and J. P. Myers. 1989. Shorebird flyways in the New World Pages $85-96$ in $H$. Boyd and J. F. Pirot, editors. Flyways and reserve networks for water birds. Special Publication No. 9. International Waterfowl and Wetlands Research Hureun, Flausestes, Fingand.

Morrison, R. I. G., and R. K. Ross. 1989. Atlas of nearctic shorebirds on the coast of South America. Vols. 1 and 2. Canadian Wildife Service Special Publication, Ottawa, Canada.

Myers, J. P. 1983. Conservation of migrating shorebirds: Staging areas, geographic bottlenecks, and regional movements. American Birds 37:23-25.

Myers, J. P., R. I. G. Morrison, P. Z. Antas, B. A. Harrington, T. E. Lovejoy, M. Sallaberry, S. E. Senner, and A. Tarak. 1987. Conservation strategy for migratory species. American Scientist 75:18-26.

National Geographic Society. 1981. National Geographic Atlas of the World. 5th Edition. National Geographic Society, Washington, D.C.

Senner, S. E., and M. A. Howe. 1984. Conservation of nearctic shorebirds. Pages 379-421 in J. Burger and B. L. Olla, editors. Shorebirds: Breeding behavior and populations. Plenum Pub"iskimg. "Wew"rotx.

Smit, C. J., and T. Piersma. 1989. Numbers, midwinter distribution, and migration of wader populations using the East Atlantic flyway. Pages $24-63$ in H. Boyd and J.-Y. Pirot, editors. Flyways and reserve networks for water birds. Special Publication No. 9. International Waterfowl and Wetlands Research Bureau, Gloucester, England.

Szaro, R. C. 2,900. Mangement of dynamic ecosystems. con cluding remarks: Pages 173-180 in J. M. Sweeney, editor. Management of dynamic ecosystems. North Central Section, The Wildife Society, West Iafayette, Indiana.

Takekawa, J. E., and S. R. Beissinger. 1989. Cyclic drought, dispersal, and the conservation of the Snail Kite in Florida: Lessons in critical habitat. Conservation Biology 3:302-311.

Tiner, R. W., Jr. 1984. Wetlands of the United States: Current status and recent trends. U.S. Fish and Wridlife Service Wetlands Inventory, Washington, D.C.

US Environmental Protection Agency. 1991. Proposed revisions to the federal manual for delineating wetlands. Washington, D.C. 


\section{Appendix}

Classification of shorebirds by migration distance. Categories of short-, intermediate, and long-distance migrants are based on an index $I$, a weighted average of $D_{s} D_{m}$ and $D_{s}$ where $D_{s}$ represents the shortest distance $(\times 1000 \mathrm{~km})$ between breeding and wintering ranges, $D_{m}$ the distance between the approximate midpoints of the ranges, and $D_{e}$ the distance between the extreme edges of the canges. Alpha codes follow Klimklewicz and Robbins (1978). Body sizes are expressed as small, medium, and large (see methods). Extent of range is given as $N$ latitude unless otherwise specified. All distance estimates are based on range maps in Hayman et al. (1986) and maps in the National Geographic Society Atlas (1981).

Sbort-dtstance Migrants

\begin{tabular}{|c|c|c|c|c|c|c|c|}
\hline \multirow[b]{2}{*}{ Alpha Code } & \multirow[b]{2}{*}{$\begin{array}{c}\text { Body } \\
\text { Stze }\end{array}$} & \multirow[b]{2}{*}{ Common Name } & \multirow[b]{2}{*}{ Scienttfic Name } & \multirow[b]{2}{*}{$\boldsymbol{I}$} & \multirow[b]{2}{*}{$\begin{array}{c}D_{m} \\
(\times 1000 \mathrm{~km}) \\
\end{array}$} & \multicolumn{2}{|c|}{$\begin{array}{c}\text { Extent of Range } \\
\text { (Lat) }\end{array}$} \\
\hline & & & & & & $\begin{array}{l}\text { Soutb } \\
\text { Breed }\end{array}$ & $\begin{array}{l}\text { North } \\
\text { Winter }\end{array}$ \\
\hline LBCU & $\mathbf{L}$ & Long-Billed Curlew & Numenius amertcanus & 1.7 & 1.7 & 35 & 40 \\
\hline SNPL & $\mathbf{s}$ & Snowy Plover & Cbaradrius alexandrinus & 2.1 & 2.0 & 30 & 45 \\
\hline AMAV & $\mathbf{L}$ & American Avocet & Recurvirostra americana & 2.1 & 2.8 & 30 & 37 \\
\hline KILL & $\mathbf{M}$ & Killdeer & Charadrius vociferus & 3.4 & 2.1 & 20 & 45 \\
\hline MAGO & $\mathbf{L}$ & Marbled Godwit & Limosa fedoa & 3.5 & 3.2 & 40 & $\mathbf{4 0}$ \\
\hline WILL & $\mathbf{L}$ & Willet & Catoptropborus semipalmatus & 3.6 & 4.2 & 40 & 40 \\
\hline $\operatorname{COSN}$ & $\mathbf{M}$ & Common Snipe & Gallinago gallinago & 3.9 & 3.7 & 38 & 50 \\
\hline SPSA & $\mathbf{M}$ & Spotted Sandpiper & Actitis macularia & 6.3 & 7.8 & 35 & 48 \\
\hline DUNL & $\mathbf{M}$ & Dunlin & Calidris alpina & 6.3 & 5.8 & 55 & 50 \\
\hline SEPL & $\mathbf{s}$ & Semipalmated Plover & Charadrtus semipalmatus & 9.4 & 10.5 & 52 & 38 \\
\hline SESA & $\mathbf{s}$ & Semipalmated Sandpiper & Calidris pusilla & 9.5 & 8.7 & 52 & 21 \\
\hline WESA & $\mathbf{S}$ & Western Sandpiper & Calidris mauri & 9.5 & 9.6 & 63 & 42 \\
\hline RNPH & $\mathbf{M}$ & Red-Necked Phalarope & Phalaropus lobatus & 9.5 & 9.5 & 55 & 35 \\
\hline LEYE & $\mathbf{M}$ & Lesser Yellowlegs & Tringa flavipes & 9.7 & 11.2 & 50 & 34 \\
\hline SOSA & $\mathbf{M}$ & Solitary Sandpiper & Tringa solitaria & 9.8 & 11.6 & 50 & 26 \\
\hline WHIM & $\mathbf{L}$ & Whimbrel & Numenius pbaeopus & 10.0 & 10.6 & 58 & 40 \\
\hline WIPH & $\mathbf{M}$ & Wilson's Phalarope & Pbalaropus tricolor & 10.1 & 9.6 & 30 & 55 \\
\hline REKN & $\mathbf{M}$ & Red Knot & Calidris canutus & 10.1 & 10.9 & 65 & 35 \\
\hline RUTU & $\mathbf{M}$ & Ruddy Turnstone & Arenaria interpnes & 11.0 & 10.7 & 62 & 40 \\
\hline SAND & $\mathbf{M}$ & Sanderling & Calidris alba & 11.4 & 11.2 & 65 & 50 \\
\hline UPSA & $\mathbf{M}$ & Upland Sandpiper & Bartramia longicauda & 12.4 & 10.7 & 36 & 205 \\
\hline LEGP & $\mathbf{M}$ & Lesser Golden Plover & Pluvialis dominica & 14.8 & 12.7 & 54 & 105 \\
\hline
\end{tabular}

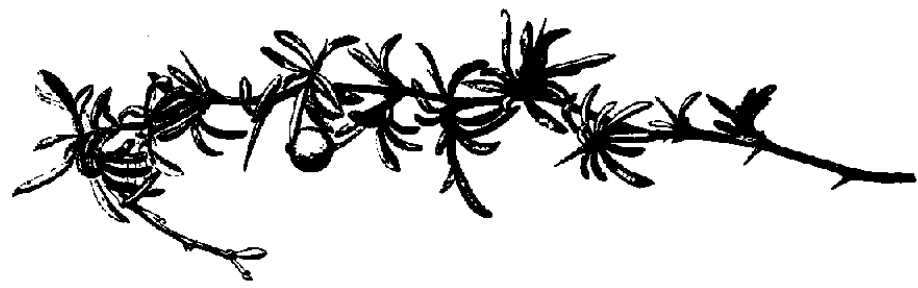

